\title{
KORELASI KEGIATAN ICE BREAKING DENGAN MOTIVASI BELAJAR PESERTA DIDIK DALAM PROSES PEMBELAJARAN TEMATIK
}

\author{
Rudiana Rahmi \\ Jurusan Pendidikan Guru Madrasah Ibtidaiyah \\ Universitas Islam Negeri Antasari Banjarmasin \\ Email: rahmi.rudiana@gmail.com
}

\begin{abstract}
This study purposed to know implementation of ice breaking activities and learning motivation of students in the thematic learning process, and correlation of ice breaking activities and learning motivation of students in the thematic learning process at MI Nurul Islam Gambut. The type of this study was field research used was quantitative approach and correlation research method. The population and the sample of this study was students of grade IV MI Nurul Islam Gambut. Data collection technique of this study were taken by questionnaire, observation, interview and documentation. Next, the data analysis technique used pearson product moment correlation analysis. The result of the study showed that ice breaking activities at MI Nurul Islam Gambut was very good. This can be seen from the observational data and questionnaire data obtaining a percentage of $75,7 \%$ and $83,6 \%$. The learning motivation of students in the thematic learning process at MI Nurul Islam Gambut was good. This can be seen from the questionnaire data obtaining a percentage of $81,8 \%$. There is a significant correlation between ice breaking activities and learning motivation of students in the thematic learning process at MI Nurul Islam Gambut. This can be seen from $r_{x y}>r_{\text {tabel }}$ that $0,864>0,735$ with a significance level $1 \%$ or $0,864>0,602$ with a significance level $5 \%$.
\end{abstract}

Key Words: ice breaking; learning motivation

\begin{abstract}
ABSTRAK
Penelitian ini bertujuan untuk mengetahui pelaksanaan kegiatan ice breaking dan motivasi belajar peserta didik dalam proses pembelajaran tematik, serta korelasi antara kegiatan ice breaking dengan motivasi belajar peserta didik dalam proses pembelajaran tematik di MI Nurul Islam Gambut. Jenis penelitian ini adalah penelitian lapangan yang menggunakan pendekatan kuantitatif serta metode penelitian korelasional. Populasi dan sampel pada penelitian ini adalah seluruh peserta didik kelas IV di MI Nurul Islam Gambut berjumlah 11 orang. Teknik pengumpulan data dalam penelitian ini diambil dengan cara angket, observasi, wawancara, dan dokumentasi. Selanjutnya dianalisis menggunakan analisis korelasi pearson product moment. Hasil penelitian menunjukkan kegiatan ice breaking di MI Nurul Islam Gambut dapat dikatakan berjalan dengan sangat baik. Hal ini terlihat dari data hasil observasi dan data angket yang memperoleh persentase sebesar $75,7 \%$ dan $83,6 \%$. Motivasi belajar peserta didik dalam proses pembelajaran tematik di MI Nurul Islam Gambut tergolong sangat baik. Hal ini terlihat dari data angket yang memperoleh persentase sebesar $81,8 \%$. Terdapat korelasi yang signifikan antara kegiatan ice breaking dengan motivasi belajar peserta didik dalam proses pembelajaran tematik di MI Nurul Islam Gambut. Hal tersebut terlihat dari $r_{x y}>r_{\text {tabel }}$ yaitu 0,864 $>0,735$ dengan taraf signifikan $1 \%$ atau $0,864>0,602$ dengan taraf signifikan $5 \%$.
\end{abstract}

Kata Kunci : ice breaking; motivasi belajar

\section{PENDAHULUAN}

Pendidikan merupakan usaha sadar dan bertujuan untuk mengembangkan kualitas manusia. Sebagai suatu kegiatan yang sadar akan tujuan, maka dalam pelaksanaannya 
berada dalam suatu proses yang berkesinambungan dalam setiap jenis dan jenjang pendidikan. Pendidikan bisa berlangsung di mana saja dan salah satu tempat berlangsungnya proses pendidikan adalah di Madrasah Ibtidaiyah. Madrasah Ibtidaiyah sebagai lembaga pendidikan tingkat dasar mengajarkan mata pelajaran agama dan juga mengajarkan mata pelajaran umum, dalam kurikulum 2013 mata pelajaran umum diajarkan dalam pembelajaran tematik.

Keberhasilan suatu pembelajaran dapat dilihat melalui proses pembelajaran yang optimal. Terdapat berbagai faktor yang menentukan keberhasilan proses belajar mengajar, di antaranya adalah motivasi peserta didik dalam mengikuti pembelajaran, termasuk dalam pembelajaran tematik. Motivasi yang tinggi pada peserta didik dalam mengikuti pembelajaran akan melahirkan aktivitas belajar yang optimal. Hal ini juga akan terlihat dari antusias peserta didik dalam mengikuti kegiatan pembelajaran.

Jika peserta didik sudah sampai pada titik jenuh atau mulai merasa bosan maka tentu peserta didik kehilangan motivasinya dalam belajar. Apabila motivasi belajar peserta didik hilang, hal tersebut akan berdampak pada prestasi belajarnya. Pada kondisi inilah guru dituntut untuk dapat mengembalikan motivasi belajar peserta didik dengan beragam cara kreatif yang perlu dilakukan guru. Salah satu cara yang bisa digunakan guru adalah dengan mengadakan kegiatan ice breaking.

Berdasarkan hasil wawancara yang peneliti lakukan di lokasi penelitian, guru pelajaran tematik kelas IV sering mengadakan beberapa kegiatan ice breaking di antaranya: permainan atau games, gerak badan, serta tebak-tebakan, hal tersebut dilakukan ketika peserta didik mulai terlihat jenuh. Setelah diadakannya kegiatan ice breaking yang dilakukan guru, terlihat kondisi peserta didik mengalami perubahan, misalnya peserta didik kembali memperhatikan apa yang sedang dipelajari dan memperhatikan apa yang disampaikan oleh guru, selain itu terlihat kejenuhan peserta didik mulai berkurang, sehingga proses pembelajaran dapat berlangsung secara optimal.

Berdasarkan hal tersebut, kemungkinan kegiatan ice breaking mampu membantu memecah kejenuhan yang dirasakan peserta didik dan mengembalikan motivasi belajar peserta didik untuk mengikuti pembelajaran. Oleh sebab itu, dilihat dari latar belakang di atas penulis tertarik untuk meneliti apakah terdapat korelasi pelaksanaan kegiatan ice breaking dengan motivasi belajar peserta didik khususnya dalam proses pembelajaran tematik di MI Nurul Islam Gambut.

Adapun yang dimaksud dengan ice breaking, menurut M. Said (2010: 1) menjelaskan bahwa ice breaking adalah suatu permainan atau kegiatan yang berfungsi untuk mengubah suasana kebekuan dalam kelompok. Menurut Sunarto (2012: 3) menjelaskan ice breaking dalam pembelajaran dapat diartikan sebagai pemecah situasi kebekuan atau fisik peserta didik. Ice breaking dimaksudkan untuk membangun suasana belajar yang dinamis, penuh semangat, dan antusiasme yang memiliki karakteristik menciptakan suasana belajar yang menyenangkan (fun) serta serius tapi santai. Ice breaking dalam proses pembelajaran terdapat beberapa jenis yaitu, jenis yel-yel; jenis tepuk tangan; jenis lagu; jenis gerak badan; jenis humor; jeins games; jenis cerita; jenis sulap; dan jenis audio visual.

Sedangkan, motivasi menurut Daryanto (2010: 2) motivasi suatu proses usaha yang dilakukan seseorang untuk memperoleh suatu perubahan tingkah laku yang baru secara keseluruhan, sebagai hasil pengalamannya sendiri dalam interaksi dengan lingkungannya. Motivasi belajar dapat diartikan gairah atau semangat peserta didik untuk belajar. Motivasi jelas diperlukan dalam kegiatan pembelajaran. Motivasi yang tinggi pada peserta didik akan melahirkan aktivitas beajar yang optimal sehingga tujuan pembelajaran dapat tercapai secara optimal. 


\section{METODE PENELITIAN}

Jenis penelitian ini adalah penelitian lapangan (field research) yang mengambil lokasi di MI Nurul Islam Gambut, dengan rentang waktu dari bulan April sampai bulan Mei 2018. Penelitian ini menggunakan pendekatan kuantitatif dengan jenis penelitian korelasional. Populasi dan sampel dalam penelitian ini adalah seluruh peserta didik kelas IV di MI Nurul Islam Gambut.

Data yang dikumpulkan terdiri dari dua data, yaitu data pokok dan data penunjang. Data pokok adalah data yang digali untuk menjawab permasalahan yang telah dirumuskan. Sedangkan, data penunjang digali sebagai pelengkap data pokok. Sumber data dalam penelitian ini ada tiga, responden, informan, dan dokumen. Responden penelitian ini adalah seluruh peserta didik kelas IV yang berjumlah 11 orang dan satu orang guru tematik kelas IV di MI Nurul Islam Gambut. Sedangkan informan terdiri dari kepala madrasah dan guru MI Nurul Islam Gambut. Dokumen dalam penelitian ini terdiri dari gambaran umum lokasi penelitian.

Teknik pengumpulan data yang digunakan dalam penelitian ini diambil dengan cara angket, observasi, wawancara, dan dokumentasi. Data yang dikumpulkan untuk mengukur pelaksanaan kegiatan ice breaking dalam penelitian ini digunakan instrumen penelitian berupa lembar observasi yang dilihat dari 7 indikator penilaian kegiatan ice breaking dengan lima kali observasi serta lembar angket yang terdiri dari 16 pertanyaan. Sedangkan untuk mengukur motivasi belajar peserta didik, digunakan intrumen penelitian berupa lembar angket yang berjumlah 32 pertanyaan. Data yang telah diperoleh selanjutnya diproses melalui penyusunan data, klasifikasi data, pengolahan data, dan interpretasi data. Selnjutnya, dianalisis menggunakan teknik analisis korelasi pearson product moment.

\section{HASIL PENELITIAN DAN PEMBAHASAN}

Berdasarkan data hasil penelitian, diperoleh data mengenai kegiatan ice breaking dalam proses pembelajaran tematik di MI Nurul Islam Gambut melalui instrumen penelitian observasi dan angket. Data hasil observasi diperoleh dari lima kali observasi kegiatan ice breaking pada proses pembelajaran tematik, dimana penilaiannya dilihat dari 7 indikator yang kemudian dipecah menjadi beberapa sub indikator. Seperti yang terlihat pada Tabel 1 di bawah ini.

Tabel 1. Data Hasil Observasi Kegiatan Ice Breaking

\begin{tabular}{|c|c|l|c|c|c|c|c|}
\hline \multirow{2}{*}{ No. } & \multirow{2}{*}{ Indikator } & \multicolumn{1}{|c|}{ Sub Indikator } & \multicolumn{5}{|c|}{ Observasi ke } \\
\cline { 3 - 7 } & Efektifitas & $\begin{array}{l}\text { Guru memilih jenis } \\
\text { kegiatan ice breaking } \\
\text { yang dapat membantu } \\
\text { tercapainya tujuan } \\
\text { pembelajaran. }\end{array}$ & 0 & 1 & 1 & 1 & 0 \\
\hline $\begin{array}{l}\text { Guru memilin kegiatan } \\
\text { ice breaking yang } \\
\text { mudah dilakukan. }\end{array}$ & 1 & 1 & 1 & 1 & 1 \\
\hline 2. & Motivasi & $\begin{array}{l}\text { Peserta didik terlihat } \\
\text { mengikuti dengan } \\
\text { antusias kegiatan ice } \\
\text { breaking yang } \\
\text { diadakan. }\end{array}$ & 1 & 1 & 1 & 1 & 1 \\
\cline { 3 - 7 } & $\begin{array}{l}\text { Peserta didik terlihat } \\
\text { mengikuti dengan aktif } \\
\text { kegiatan ice breaking }\end{array}$ & 1 & 1 & 1 & 1 & 1 \\
\hline
\end{tabular}




\begin{tabular}{|c|c|c|c|c|c|c|c|}
\hline \multirow{5}{*}{ No. } & \multirow{5}{*}{ Indikator } & \multirow{2}{*}{ Sub Indikator } & \multicolumn{5}{|c|}{ Observasi ke } \\
\hline & & & 1 & 2 & 3 & 4 & 5 \\
\hline & & yang diadakan. & & & & & \\
\hline & & $\begin{array}{l}\text { Guru memilih kegiatan } \\
\text { ice breaking yang } \\
\text { dapat membangkitkan } \\
\text { perhatian peserta } \\
\text { didik. }\end{array}$ & 1 & 1 & 1 & 1 & 1 \\
\hline & & $\begin{array}{l}\text { Setelah mengikuti } \\
\text { kegiatan ice breaking, } \\
\text { peserta didik terlihat } \\
\text { lebih bersemangat } \\
\text { dalam mengikuti } \\
\text { pembelajaran } \\
\text { dibanding sebelum } \\
\text { diadakannya ice } \\
\text { breaking. }\end{array}$ & 1 & 1 & 1 & 1 & 1 \\
\hline 3. & Sinkronized & $\begin{array}{l}\text { Guru memilih kegiatan } \\
\text { ice breaking yang } \\
\text { sesuai dengan materi } \\
\text { yang diajarkan. }\end{array}$ & 0 & 1 & 1 & 1 & 0 \\
\hline 4. & $\begin{array}{c}\text { Tidak } \\
\text { berlebihan }\end{array}$ & $\begin{array}{l}\text { Pemilihan kegiatan ice } \\
\text { breaking yang } \\
\text { diterapkan tidak } \\
\text { menyita durasi waktu } \\
\text { kegiatan belajar } \\
\text { mengajar. }\end{array}$ & 0 & 1 & 0 & 1 & 1 \\
\hline 5. & Tepat situasi & $\begin{array}{l}\text { Guru menerapkan } \\
\text { kegiatan ice breaking } \\
\text { ketika peserta didik } \\
\text { mulai terlihat jenuh. }\end{array}$ & 1 & 1 & 1 & 0 & 0 \\
\hline & & $\begin{array}{l}\text { Guru menerapkan } \\
\text { kegiatan ice breaking } \\
\text { ketika situasi kelas } \\
\text { mulai tidak kondusif. }\end{array}$ & 0 & 0 & 0 & 0 & 1 \\
\hline & & $\begin{array}{l}\text { Pemilihan kegiatan ice } \\
\text { breaking yang } \\
\text { diterapkan tidak } \\
\text { menjadikan pengerjaan } \\
\text { tugas peserta didik } \\
\text { menjadi tidak fokus. }\end{array}$ & 0 & 0 & 1 & 1 & 1 \\
\hline & & $\begin{array}{l}\text { Pemilihan kegiatan ice } \\
\text { breaking yang } \\
\text { diterapkan tidak } \\
\text { membuat kelas } \\
\text { menjadi gaduh. }\end{array}$ & 1 & 0 & 0 & 1 & 0 \\
\hline 6. & $\begin{array}{c}\text { Tidak } \\
\text { mengandung } \\
\text { unsur SARA }\end{array}$ & $\begin{array}{l}\text { Pemilihan kegiatan ice } \\
\text { breaking yang } \\
\text { diterapkan tidak } \\
\text { membedakan atau } \\
\text { menghina Suku, } \\
\text { Agama, Ras, dan } \\
\text { Antar Golongan. }\end{array}$ & 1 & 1 & 1 & 1 & 1 \\
\hline
\end{tabular}




\begin{tabular}{|c|c|c|c|c|c|c|c|}
\hline \multirow{2}{*}{ No. } & \multirow{2}{*}{ Indikator } & \multirow{2}{*}{ Sub Indikator } & \multicolumn{5}{|c|}{ Observasi ke } \\
\hline & & & 1 & 2 & 3 & 4 & 5 \\
\hline 7. & $\begin{array}{c}\text { Tidak } \\
\text { mengandung } \\
\text { unsur } \\
\text { pornografi }\end{array}$ & $\begin{array}{l}\text { Pemilihan kegiatan ice } \\
\text { breaking yang } \\
\text { diterapkan tidak } \\
\text { mengandung unsur } \\
\text { pornografi. }\end{array}$ & 1 & 1 & 1 & 1 & 1 \\
\hline \multicolumn{3}{|c|}{ Jumlah } & 9 & 11 & 11 & 12 & 10 \\
\hline \multicolumn{3}{|c|}{ Persentase yang diperoleh } & $64,3 \%$ & $78,6 \%$ & $78,6 \%$ & $85,7 \%$ & $71,4 \%$ \\
\hline
\end{tabular}

Keterangan :

1 = kegiatan pada sub indikator terlaksana

0 = kegiatan pada sub indikator tidak terlaksana

Hasil persentase di atas, kemudian diinterpretasikan menggunakan kategori penilaian skala (rating scale) seperti pada Tabel 2 berikut:

Tabel 2. Interpretasi Kategori Penilaian Skala (Rating Scale)

\begin{tabular}{|c|c|}
\hline Persentase & Predikat \\
\hline $0>20 \%$ & Sangat lemah/kurang sekali \\
\hline $21 \%>40 \%$ & Lemah/kurang \\
\hline $41 \%>60 \%$ & Cukup \\
\hline $61 \%>80 \%$ & Kuat/baik \\
\hline $80 \%>100 \%$ & Sangat kuat/sangat baik \\
\hline
\end{tabular}

Sehingga dapat diperoleh data bahwa observasi pertama kegiatan ice breaking dengan jenis permainan diperoleh persentase sebesar 64,3\% dengan kategori baik. Observasi ke-2 kegiatan ice breaking dengan jenis lagu dan tepuk diperoleh persentase sebesar 78,6\% dengan kategori baik. Observasi ke-3 kegiatan ice breaking dengan jenis tebak-tebakan diperoleh persentase sebesar 78,6\% dengan kategori baik. Selanjutnya, observasi ke-4 kegiatan ice breaking dengan jenis permainan diperoleh persentase sebesar 85,7\% dengan kategori sangat baik. Terakhir, observasi ke-5 kegiatan ice breaking dengan jenis tepuk diperoleh persentase sebesar $71,4 \%$, dengan kategori baik.

Selanjutnya, agar dapat diketahui gambaran umum mengenai kegiatan ice breaking yang telah terlaksana, hasil persentase pada Tabel 1 dihitung kembali menggunakan rumus mean, sehingga diperoleh perhitungan sebagai berikut.

$$
M=\frac{\Sigma X}{N}=\frac{64,3 \%+78,6 \%+78,6 \%+85,7 \%+71,4 \%}{5}=\frac{378,6 \%}{5}=75,7 \%
$$

Keterangan :

$M \quad=$ Mean yang dicari

$\Sigma X \quad=$ Jumlah keseluruhan nilai

$N \quad=$ jumlah item

Jika dikonsultasikan dengan kriteria rating scale seperti pada Tabel 2, dapat disimpulkan bahwa kegiatan ice breaking yang telah terlaksana mendapatkan persentase sebesar 75,7\% dengan kategori "baik", yang artinya jika dilihat dari hasil observasi kegiatan ice breaking dalam proses pembelajaran tematik di MI Nurul Islam Gambut terlaksana dengan baik. 
Selanjutnya, berikut hasil penelitian untuk menggali data kegiatan ice breaking dilihat dari lembar angket. Angket terdiri dari 32 pertanyaan yang disebar pada 11 orang peserta didik kelas IV MI Nurul Islam Gambut. Angket terdiri dari 16 pertanyaan untuk menggali data mengenai kegiatan ice breaking dan 16 pertanyaan untuk menggali data mengenai motivasi belajar peserta didik.. Setiap skor diperoleh berdasarkan penilaian berikut.

Tabel 3. Skor Alternatif Jawaban Angket

\begin{tabular}{|c|c|c|c|c|c|}
\hline Arah Pertanyaan & Sangat Setuju & Setuju & Ragu & Tidak Setuju & Sangat Tidak Setuju \\
\hline Positif & 5 & 4 & 3 & 2 & 1 \\
\hline Negatif & 1 & 2 & 3 & 4 & 5 \\
\hline
\end{tabular}

Berdasarkan skor dan pertanyaan pada lembar angket diperoleh hasil seperti pada tabel 4 berikut.

Tabel 4. Data Hasil Skor Angket Kegiatan Ice Breaking

\begin{tabular}{|c|c|c|c|c|c|c|c|c|c|c|c|c|c|c|c|c|c|}
\hline \multirow{2}{*}{ No. } & \multicolumn{16}{|c|}{ Nomor Item Pernyataan } & \multirow{2}{*}{ Total } \\
\hline & 2 & 3 & 4 & 5 & 8 & 9 & 12 & 14 & 15 & 19 & 21 & 22 & 26 & 27 & 28 & 32 & \\
\hline 1 & 5 & 5 & 4 & 5 & 4 & 5 & 3 & 5 & 4 & 3 & 3 & 2 & 3 & 5 & 3 & 5 & 64 \\
\hline 2 & 5 & 5 & 4 & 5 & 4 & 4 & 4 & 5 & 4 & 5 & 4 & 5 & 4 & 5 & 4 & 5 & 72 \\
\hline 3 & 5 & 4 & 4 & 4 & 4 & 4 & 4 & 5 & 4 & 4 & 4 & 4 & 4 & 4 & 4 & 4 & 66 \\
\hline 4 & 4 & 4 & 4 & 5 & 4 & 4 & 3 & 4 & 3 & 3 & 3 & 4 & 3 & 4 & 3 & 2 & 57 \\
\hline 5 & 5 & 3 & 4 & 5 & 3 & 3 & 4 & 5 & 5 & 5 & 3 & 5 & 3 & 5 & 3 & 5 & 66 \\
\hline 6 & 5 & 5 & 4 & 5 & 4 & 4 & 3 & 4 & 4 & 4 & 3 & 4 & 3 & 4 & 4 & 4 & 64 \\
\hline 7 & 5 & 4 & 5 & 4 & 4 & 4 & 3 & 4 & 4 & 4 & 5 & 5 & 4 & 5 & 4 & 4 & 68 \\
\hline 8 & 5 & 5 & 4 & 5 & 4 & 4 & 4 & 5 & 4 & 5 & 4 & 5 & 4 & 5 & 4 & 5 & 72 \\
\hline 9 & 5 & 3 & 4 & 5 & 4 & 4 & 3 & 5 & 4 & 4 & 4 & 5 & 4 & 5 & 4 & 4 & 67 \\
\hline 10 & 4 & 4 & 5 & 4 & 5 & 4 & 5 & 5 & 4 & 5 & 4 & 4 & 4 & 4 & 5 & 4 & 70 \\
\hline 11 & 5 & 4 & 4 & 5 & 4 & 4 & 4 & 5 & 5 & 5 & 4 & 5 & 4 & 4 & 4 & 4 & 70 \\
\hline $\mathbf{J m l}$ & 53 & 46 & 46 & 52 & 44 & 44 & 40 & 52 & 45 & 47 & 41 & 48 & 40 & 50 & 42 & 46 & 736 \\
\hline
\end{tabular}

Tabel 5. Data Hasil Skor Angket Motivasi Belajar Peserta Didik

\begin{tabular}{|c|c|c|c|c|c|c|c|c|c|c|c|c|c|c|c|c|c|}
\hline \multirow{2}{*}{ No. } & \multicolumn{16}{|c|}{ Nomor Item Pernyataan } & \multirow{2}{*}{ Total } \\
\hline & 1 & 6 & 7 & 10 & 11 & 13 & 16 & 17 & 18 & 20 & 23 & 24 & 25 & 29 & 30 & 31 & \\
\hline 1 & 5 & 5 & 4 & 3 & 3 & 3 & 3 & 3 & 3 & 2 & 3 & 3 & 4 & 5 & 5 & 5 & 59 \\
\hline 2 & 4 & 5 & 4 & 5 & 5 & 4 & 4 & 4 & 4 & 5 & 4 & 4 & 5 & 4 & 4 & 5 & 70 \\
\hline 3 & 4 & 5 & 5 & 4 & 4 & 3 & 4 & 4 & 5 & 4 & 4 & 4 & 5 & 4 & 4 & 5 & 68 \\
\hline 4 & 4 & 4 & 3 & 4 & 3 & 4 & 3 & 4 & 3 & 4 & 3 & 3 & 3 & 4 & 3 & 5 & 57 \\
\hline 5 & 3 & 3 & 5 & 3 & 3 & 3 & 3 & 5 & 5 & 3 & 3 & 3 & 5 & 3 & 5 & 5 & 60 \\
\hline 6 & 5 & 4 & 4 & 5 & 4 & 5 & 3 & 3 & 3 & 2 & 4 & 2 & 5 & 4 & 3 & 5 & 61 \\
\hline 7 & 4 & 4 & 5 & 5 & 5 & 5 & 5 & 5 & 5 & 4 & 3 & 2 & 5 & 2 & 4 & 4 & 67 \\
\hline 8 & 4 & 5 & 4 & 5 & 4 & 4 & 4 & 4 & 4 & 5 & 4 & 4 & 5 & 4 & 4 & 5 & 69 \\
\hline 9 & 5 & 3 & 5 & 4 & 5 & 3 & 3 & 5 & 5 & 4 & 4 & 3 & 5 & 4 & 5 & 5 & 68 \\
\hline 10 & 5 & 4 & 5 & 5 & 5 & 5 & 5 & 4 & 4 & 4 & 4 & 4 & 4 & 4 & 4 & 5 & 71 \\
\hline
\end{tabular}




\begin{tabular}{|c|c|c|c|c|c|c|c|c|c|c|c|c|c|c|c|c|c|}
\hline \multirow{2}{*}{ No. } & \multicolumn{11}{|c|}{ Notal } \\
\cline { 2 - 18 } & $\mathbf{1}$ & $\mathbf{6}$ & $\mathbf{7}$ & $\mathbf{1 0}$ & $\mathbf{1 1}$ & $\mathbf{1 3}$ & $\mathbf{1 6}$ & $\mathbf{1 7}$ & $\mathbf{1 8}$ & $\mathbf{2 0}$ & $\mathbf{2 3}$ & $\mathbf{2 4}$ & $\mathbf{2 5}$ & $\mathbf{2 9}$ & $\mathbf{3 0}$ & $\mathbf{3 1}$ & \\
\hline $\mathbf{1 1}$ & 5 & 5 & 4 & 4 & 4 & 5 & 4 & 4 & 4 & 5 & 4 & 4 & 4 & 5 & 4 & 5 & $\mathbf{7 0}$ \\
\hline Jml & $\mathbf{4 8}$ & $\mathbf{4 7}$ & $\mathbf{4 8}$ & $\mathbf{4 7}$ & $\mathbf{4 5}$ & $\mathbf{4 4}$ & $\mathbf{4 1}$ & $\mathbf{4 5}$ & $\mathbf{4 5}$ & $\mathbf{4 2}$ & $\mathbf{4 0}$ & $\mathbf{3 6}$ & $\mathbf{5 0}$ & $\mathbf{4 3}$ & $\mathbf{4 5}$ & $\mathbf{5 4}$ & $\mathbf{7 2 0}$ \\
\hline
\end{tabular}

Selanjutnya, untuk menganalisis data angket seperti pada Tabel 4 dan Tabel 5, digunakan rumus jumlah skor kriterium dan hasil perhitungan data, sehingga diperoleh data berikut.

Jumlah skor kriterium $=$ skor tertinggi tiap item $x$ jumlah item $x$ jumlah responden

$=5 \times 16 \times 11$

$=880$

Hasil perhitungan data = Jumlah skor frekuensi : jumlah skor kriterium $\times 100 \%$

$=736: 880 \times 100 \%$

$=83,6 \%$

Jika dikonsultasikan dengan kriteria rating scale pada Tabel 2, dapat disimpulkan bahwa kegiatan ice breaking dalam proses pembelajaran tematik mendapatkan persentase sebesar 83,6\% termasuk kategori "sangat baik", yang artinya jika dilihat dari hasil angket kegiatan ice breaking dalam proses pembelajaran tematik di MI Nurul Islam Gambut terlaksana sangat baik.

Jumlah skor kriterium $=$ skor tertinggi tiap item $x$ jumlah item $x$ jumlah responden

$=5 \times 16 \times 11$

$=880$

Hasil perhitungan data = Jumlah skor frekuensi : jumlah skor kriterium $\times 100 \%$

$=720: 880 \times 100 \%$

$=81,8 \%$

Jika dikonsultasikan dengan kriteria rating scale pada Tebl 2, dapat disimpulkan bahwa motivasi belajar peserta didik dalam proses pembelajaran tematik mendapatkan persentase sebesar $81,8 \%$ termasuk kategori "sangat baik", yang artinya jika dilihat dari hasil angket motivasi belajar peserta didik dalam proses pembelajaran tematik di MI Nurul Islam Gambut sangat baik. Data yang diperoleh seperti pada Tabel 4 dan Tabel 5 dimasukkan dalam tabel skor total angket variabel $\mathrm{X}$ dan variabel $\mathrm{Y}$ pada masing-masing responden seperti berikut.

Tabel 6. Skor Total Data Angket Variabel X dan Variabel Y

\begin{tabular}{|c|c|c|c|}
\hline No. & Reponden & X & Y \\
\hline 1 & Siswa 1 & 64 & 59 \\
\hline 2 & Siswa 2 & 72 & 70 \\
\hline 3 & Siswa 3 & 66 & 68 \\
\hline 4 & Siswa 4 & 57 & 57 \\
\hline 5 & Siswa 5 & 66 & 60 \\
\hline 6 & Siswa 6 & 64 & 61 \\
\hline 7 & Siswa 7 & 68 & 67 \\
\hline 8 & Siswa 8 & 72 & 69 \\
\hline 9 & Siswa 9 & 67 & 68 \\
\hline 10 & Siswa 10 & 70 & 71 \\
\hline 11 & Siswa 11 & $\mathbf{7 3 6}$ & 70 \\
\hline & Jumlah & & $\mathbf{7 2 0}$ \\
\hline
\end{tabular}


Mengetahui ada tidaknya korelasi yang signifikan antara kegiatan ice breaking (variabel $\mathrm{X}$ ) dengan motivasi belajar peserta didik (variabel $\mathrm{Y}$ ), penulis menggunakan rumus Korelasi Pearson Product Moment menggunakan bantuan SPSS version 15.0 for widows, sehingga diperoleh hasil berikut.

Tabel 7. Hasil Perhitungan Korelasi Pearson Product Moment Correlations

\begin{tabular}{|ll|r|r|}
\hline & \multicolumn{1}{|c|}{$\begin{array}{c}\text { X_Ice_- } \\
\text { Breaking }\end{array}$} & $\begin{array}{c}\text { Y_Motivasi_ } \\
\text { Belajar }\end{array}$ \\
\hline X_lce_Breaking & Pearson Correlation & 1 &, $864^{\star *}$ \\
& Sig. (2-tailed) & &, 001 \\
& N & 11 & 11 \\
\hline Y_Motivasi_Belajar & Pearson Correlation &, $864^{\star *}$ & 1 \\
& Sig. (2-tailed) &, 001 & 11 \\
& N & 11 & \\
\end{tabular}

${ }^{* *}$. Correlation is significant at the 0.01 level (2-tailed).

Pada perhitungan di atas, diperoleh koefisien korelasi $\left(\mathrm{r}_{\mathrm{xy}}\right)$ sebesar 0,864 . Pemberian interpretasi mengenai besarnya koefisien korelasi terdapat dua cara, yaitu:

a. Interpretasi secara kasar/sederhana

Perhitungan di atas telah diperoleh $\mathrm{r}_{\mathrm{xy}}$ sebesar 0,864, ini menunjukkan terdapat hubungan yang searah/korelasi positif antara variabel $\mathrm{X}$ dengan variabel $\mathrm{Y}$. Apabila dilihat besarnya $r_{x y}$ yang diperoleh, yaitu 0,864 ternyata terletak antara $0,800-1,000$ yang dapat dinyatakan bahwa korelasi antara variabel $\mathrm{X}$ dan variabel $\mathrm{Y}$ tergolong sangat tinggi. Maka, dengan demikian dapat dikemukakan bahwa terdapat korelasi positif yang signifikan/meyakinkan antara kegiatan ice breaking dengan motivasi belajar peserta didik.

b. Interpretasi dengan menggunakan Tabel Nilai r Pearson Product Moment, dengan langkah-langkah sebagai berikut:

1) Merumuskan hipotesis alternatif $\left(\mathrm{H}_{\mathrm{a}}\right)$ : Terdapat korelasi yang signifikan antara kegiatan ice breaking dengan motivasi belajar peserta didik dalam proses pembelajaran tematik di MI Nurul Islam Gambut.

2) Merumuskan hipotesis nihil $\left(\mathrm{H}_{0}\right)$ : Tidak terdapat korelasi yang signifikan antara kegiatan ice breaking dengan motivasi belajar peserta didik dalam proses pembelajaran tematik di MI Nurul Islam Gambut.

3) Berkonsultasikan dengan Tabel Nilai r Pearson Product Moment:

a) $\mathrm{r}_{\text {tabel }}$ pada taraf signifikan $5 \%$ dengan $\mathrm{N}=11$ adalah 0,602 .

b) $r_{\text {tabel }}$ pada taraf signifikan $1 \%$ dengan $\mathrm{N}=11$ adalah 0,735 .

4) Membandingkan besar $r_{x y}$ dengan $r_{\text {tabel }}$

$r_{x y}$ sebesar 0,864 sedangkan $r_{\text {tabel }}$ pada taraf signifikan 5\% dengan $\mathrm{N}=11$ adalah 0,602 dan $\mathrm{r}_{\text {tabel }}$ pada taraf signifikan $1 \%$ dengan $\mathrm{N}=11$ adalah 0,735 . Ketentuannya apabila $\mathrm{r}_{\text {hitung }}$ atau $r_{x y}<r_{\text {tabel, }}$, maka $\mathrm{H}_{0}$ diterima dan $\mathrm{H}_{\mathrm{a}}$ ditolak. Tetapi sebaliknya, apabila $\mathrm{r}_{\text {hitung }}$ atau $\mathrm{r}_{\mathrm{xy}}>\mathrm{r}_{\text {tabel }}$, maka $\mathrm{H}_{\mathrm{a}}$ diterima dan $\mathrm{H}_{0}$ ditolak.

Berdasarkan ketentuan tersebut terdapat bahwa $r_{x y}>r_{\text {tabel }}$, maka hipotesis alternatif $\left(\mathrm{H}_{\mathrm{a}}\right)$ : "Terdapat korelasi yang signifikan antara kegiatan ice breaking dengan motivasi belajar peserta didik dalam proses pembelajaran tematik di MI Nurul Islam Gambut" diterima, sedangkan hipotesis nihil $\left(\mathrm{H}_{0}\right)$ : "Tidak terdapat korelasi yang signifikan antara kegiatan ice breaking dengan motivasi belajar peserta didik dalam proses pembelajaran tematik di MI Nurul Islam Gambut" ditolak. Kesimpulan yang dapat ditarik adalah : Terdapat korelasi yang signifikan antara kegiatan ice breaking dengan motivasi belajar peserta didik dalam proses pembelajaran tematik di MI Nurul Islam Gambut. 
Berdasarkan kesimpulan di atas, terbukti bahwa ice breaking memiliki korelasi dengan motivasi belajar. Hal tersebut juga didasari dari salah satu fungsi dan tujuan ice breaking yaitu untuk menumbuhkan dan meningkatkan motivasi belajar peserta didik dalam proses pembelajaran. Selain itu, kesimpulan di atas juga terlihat dari hasil penelitian yang mana peserta didik mengalami perubahan tingkah laku sebelum dan sesudah diadakannya kegiatan ice breaking, keadaan peserta didik yang sebelumnya jenuh dapat diatasi dengan kegiatan ice breaking sehingga membangkitkan kembali motivasi belajar peserta didik dalam proses pembelajaran.

\section{PENUTUP}

Berdasarkan hasil penelitian dan analisis data yang telah diuraikan, maka dapat diambil beberapa kesimpulan, yaitu kegiatan ice breaking dalam proses pembelajaran tematik di MI Nurul Islam Gambut dilihat dari data hasil observasi dapat dikatakan berjalan dengan baik. Sedangkan, dilihat dari data hasil angket, kegiatan ice breaking dapat dikatakan berjalan dengan sangat baik. Hal ini dapat dibuktikan dari data hasil observasi yang memperoleh persentase sebesar $75,7 \%$ dan data hasil angket yang memperoleh persentase sebesar $83,6 \%$. Motivasi belajar peserta didik dalam proses pembelajaran tematik di MI Nurul Islam Gambut tergolong sangat baik. Hal ini dibuktikan dari data hasil angket yang memperoleh persentase sebesar $81,8 \%$. Terdapat korelasi yang signifikan antara kegiatan ice breaking dengan motivasi belajar peserta didik dalam proses pembelajaran tematik di MI Nurul Islam Gambut. Hal tersebut terlihat dari $r_{x y}>r_{\text {tabel }}$ yaitu $0,864>0,735$ dengan taraf signifikan $1 \%$ atau $0,864>0,602$ dengan taraf signifikan $5 \%$.

Berdasarkan hasil penelitian dan pembahas, dapat disampaikan saran-saran sebagai berikut. Kepada guru, khususnya guru mata pelajaran tematik hendaknya memperhatikan motivasi belajar peserta didik dalam proses pembelajaran tematik agar terjaga dalam kondisi yang tinggi, salah satunya dengan diselingi kegiatan ice breaking. Kepada peserta didik, hendaknya dapat lebih aktif dan semangat dalam mengikuti pembelajaran tematik agar motivasi belajar tetap terjaga dalam kondisi baik sehingga prestasi belajar juga akan baik.

\section{DAFTAR PUSTAKA}

Arifin, Zainal. (2014). Penelitian Pendidikan. Bandung: Remaja Rosdakarya.

Arikunto, Suharsimi. (2005). Dasar-Dasar Evaluasi Pendidikan, Jakarta: Bumi Aksara.

Baharuddin \& Esa Nur Wahyuni. (2015). Teori Belajar dan Pembelajaran, Yogyakarta: Ar-Ruzz Media.

Daryanto. (2010). Belajar dan Mengajar. Bandung: Yrama Widya.

Departemen Agama RI. (2010). Al-Qur'an dan Tafsirnya (Edisi yang Disempurnakan). Jakarta: Lentera Abadi.

Djamarah, Syaiful Bahri. (2014). Guru dan Anak Didik dalam Interaksi Edukatif. Jakarta: Rineka Cipta.

. (2011). Psikologi Belajar. Jakarta: Rineka Cipta.

Juwariyah. (2010). Pendidikan Anak dalam Al-Quran. Yogyakarta: Teras.

M.Said. (2010). 80+ Ice Breaker Games: Kumpulan Permainan Penggugah Semangat. Yogyakarta: Andi Offset.

Margono. (2012). Metodologi Penelitian Pendidikan. Jakarta: Rineka Cipta.

Maryanto. (2017). Tema 9 Kayanya Negeriku Buku Tematik Terpadu kurikulum 2013 Edisi Revisi 2017. Jakarta: Kementerian Pendidikan dan Kebudayaan.

Murdan. (2012) Statistik Pendidikan dan Aplikasinya. Banjarmasin: Cyprus Banjarmasin.

Priansa, Donni Juni. (2015). Manajemen Peserta Didik dan Model Pembelajaran. Bandung: Alfabeta. 
Putra, Winkanda Satria. (2016). 99 Permainan Edukatif untuk Melatih Kecerdasan dan Kreativitas Anak. Yogyakarta: Katahati.

Riduwan. (2005). Belajar Mudah Penelitian untuk Guru-Karyawan dan Peneliti Pemula. Bandung: Alfabeta.

. (2012). Dasar-dasar Statistika. Bandung: Alfabeta.

Sardiman. (2007). Interaksi dan Motivasi Belajar Mengajar. Jakarta: RajaGrafindo Persada.

Sarwono, Jonathan \& Hendra Nur Salim. (2017). Prosedur-prosedur Populer Statistik untuk Analisis Data Riset Skripsi. Yogyakarta: Gava Media.

Setiawan, Aries. (2010). Ice Breakers For Teachers 110 Kiat Penggairah Suasana Belajar Mengajar dalam Kelas. Surabaya: Eduvision Press.

Soenarno, Adi. (2005). Ice Breaker Permainan Atraktif-Edukatif. Yogyakarta: Andi Offset.

Sudaryono. (2017). Metodologi Penelitian. Jakarta: RajaGrafindo Persada.

Sudjana, Nana. (2017). Penilaian Hasil Proses Belajar Mengajar. Bandung: Remaja Rosdakarya.

Sugiyono. (2015). Statistika untuk Penelitian. Bandung: Alfabeta.

Sumantri, Mohamad Syarif. (2015). Strategi Pembelajaran Teori dan Praktik di Tingkat Pendidikan Dasar. Jakarta: RajaGrafindo Persada.

Sunarto. (2012). Ice Breaker dalam Pembelajaran Aktif. Surakarta: Cakrawala Media.

Suyanto \& Asep Jihad. (2013). Menjadi Guru Profesional. Jakarta: Erlangga.

Widiasworo, Erwin. (2015). 19 Kiat Sukses Membangkitkan Motivasi Belajar Peserta Didik. Yogyakarta: Ar-Ruzz Media. 